\title{
REGIONAL DIFFERENCES IN LABOR MARKET DISCRIMINATION
}

\author{
Kwabena Gyimah-Brempong and Rudy Fichtenbaum*
}

\begin{abstract}
Using a docomposition methodology developed by Neumark and 1987 CPS data to investigate the regional differences in labor market discrimination in the United Stntes, we find that there are minor regional differences in the wage gap between males and females and between blacks and whites. However, we find that there is large regional variation in the components of the wage gap that is due to labor market discrimination. We find that the regions with the largest wage gaps are not necessarily the regions with the largest labor market discrimination.
\end{abstract}

\section{INTRODUCTION}

This paper uses a decomposition analysis developed by Neumark (1988) and 1987 CPS data to investigate whether there are significant regional differences in labor market discrimination in the United States. Regional differences in malefemale (black-white) wage differentials could be due to regional differences in the male-female (white-black) gap in the endowments of productivity characteristics or due to regional differences in the male-female (blacks and whites) returns gap for these characteristics. The source of regional differences in male-female (black-white) wage differential can be established by decomposing the wage differential in each region into two components: (1) differences in characteristics across regions and (2) differences in returns to characteristics across regions. We analyze the wage differentials for males and females and blacks and whites for four geographic regions of the United States: Northeast, Midwest, South, and West. In addition, we also conduct the analysis for the nine U.S. Census Divisions-New England, Middle Atlantic, East North Central, West North Central, East South Central, West South Central, South Atlantic, Mountain, and Pacific-for the male-female wage differential.

In recent years, numerous studies have examined the persistence of the wage gap between males and females and blacks and whites. A number of authors attribute a large part of the differential to discrimination (Cotton 1988; Neumark 1988; Boston 1988; Reimers 1983; Blinder 1973; Oaxaca 1973; Gyimah-Brempong, Fichtenbaum, and Willis 1992). In contrast, a significant number of studies

\footnotetext{
*Professors of Economics, Wright State University, Dayton, Ohio. An earlier version of this paper was presented at the 16th annual meetings of the Eastern Economic Association, Pittsburgh. Pennsylvania, March 15-17, 1991. We thank three anonymous referees of The Review for helpful comments on an earlier draft of the paper.
} 
conclude that differences in measurable characteristics explain essentially all of the variation in wages between males and females and between blacks and whites (O'Neil 1990; Paglin and Rufolo 1990; Filer 1985; Butler 1982; Kamalich and Polachek 1982). Investigating regional differences in wage differentials and their sources would be another way of shedding some light on the debate. If it is found that a large part of the regional differences in the wage gap is due to regional differences in the endowment gap, that would tend to support the human capital hypothesis. On the other hand, a finding that a large part of the regional differences in the wage gap is due to differences in returns will tend to support those who argue that a large part of the wage gap is attributable to discrimination.

O'Neil (1990) argues that one of the major reasons for the narrowing of the black-white wage gap between 1940 and 1960 was the migration of blacks from the South to the North. This argument implies regional differences in the blackwhite wage gap. For policy purposes, it is important to know the sources of these regional differences in the wage differential: Are they due to regional differences in the human capital gap or to differences in labor market discrimination? Kamalich and Polacheck (1982), using reverse regression methodology, find no discrimination against blacks (females) in the United States. They also indicated that there is no regional variation in "non-discrimination" in the labor market, although they did not report any of their calculations for the regions.

Many of the studies cited above include regional dummy variables in their wage equations to account for differences in wage structures among regions. However, this implicitly assumes that retums to characteristics, and hence discrimination, are uniform in all regions of the country. In the cases of both malefemale and black-white wage differentials, this assumption may be unwarranted. Recent U.S. history points to substantial differences in attitudes toward racial and gender discrimination among the regions. If there are regional differences in returns to characteristics, then previous estimates of discrimination that have used aggregate data over wide geographical areas may be biased toward finding no wage discrimination. Low and Villegas (1987) have argued that unless males and females (blacks and whites) are employed at the same level, the estimate of labor market discrimination would be biased downward even if the marginal productivities of both groups are the same. Given that there are different regional labor markets with different male/female (white/black) employment ratios in the United States, an estimate of labor market discrimination using aggregate U.S. data would be biased downward.

Accounting for regional differences in labor market research is particularly important when studying changes in labor market discrimination over time because what appear to be changes in returns to characteristics over time can, in fact, be due to shifts in population from one region to another (Reich 1988). 
Similarly, it is also possible that significant changes in wage differentials in regions are obscured by population shifts. It is important to disaggregate by region in order to reduce this potential bias. From a policy point of view, regional differences in labor market discrimination could provide inputs into the formulation of policies to reduce labor market discrimination at the national level.

For the most part, previous studies rely on a decomposition approach popularized by Oaxaca (1973) and Blinder (1973) (hereafter Oaxaca decomposition). However, this approach will over- or underestimate labor market discrimination depending upon whether the researcher uses the lower or the higher wage as the reference wage in the decomposition analysis. Thus, in estimating regional differences in returns to characteristics, one should use a discrimination free wage structure as the basis for decomposition. We therefore use Neumark's (1988) decomposition analysis, which is based on a discrimination-free wage structure, in this study.

The use of decomposition analysis to measure labor market discrimination has been criticized by some researchers. One line of criticism is that the variables used to proxy productivity characteristics mismeasure true productivity characteristics such as motivation and the quality of education (Kamalich and Polacheck 1982; Paglin and Rufolo 1990). Paglin and Rufolo (1990), for example, argue that once you control for differences in the scientific and mathematical aptitudes between males and females, the gender wage gap completely disappears. They therefore caution that studies that do not control for college majors may overestimate labor market discrimination and underestimate the effects of human capital. However, a recent study by Haberfeld and Shenhav (1990), which controls for college degree and discipline of study, shows not only a persistence of race and sex discrimination among scientific workers, but a worsening of discrimination in the 1980s.

Our study uses CPS data, which do not provide information about the quality of education. However, to the extent that the quality and type of education influences occupational choices, occupation can be seen as a proxy for quality and type of education. Therefore, in defining human capital, we include occupations in the vector of variables that represent human capital. To the extent that occupational choices may be influenced by discrimination either in the educational process (blacks generally tend to go to low-quality schools) or in the hiring process (women are channeled into certain occupations), the inclusion of occupational variables as proxies for the quality of human capital will underestimate the true degree of discrimination. It is also possible that occupations do not capture the "quality" of education and other factors (e.g., motivation) that affect differences in worker productivity, hence differences in wages. In that case, decomposition analysis will overestimate labor market discrimination. This may be 
especially true in this study where the two-digit occupational classification we use may not be detailed enough to capture differences in the "quality" of education among workers within an occupational classification. The inability to accurately measure all productivity determining factors is a weakness of decomposition analysis, including this study.

The rest of this paper is organized as follows: Section II, following this introduction, introduces the decomposition methodology. Section III discusses the data used in this paper, while Section IV discusses the results of the decomposition analysis. Section $\mathrm{V}$ provides summary and conclusions.

\section{MODEL OF DECOMPOSITION}

Oaxaca's decomposition analysis explains the male-female (black-white) wage differential in terms of objective explanatory characteristics (endowments) and treatment effects (discrimination). It starts with an equation explaining the wage rate for each gender (race). Such an equation is given as:

$$
\ln W^{j}=X^{j} \beta^{j}+e_{j}, j=\text { male, female }
$$

where $W$ is the wage rate, $X^{\prime}$ is a vector of variables reflecting productivity and personal characteristics as well as labor market structure, $e_{j}$ is a stochastic error term, and $\beta$ is a vector of coefficients to be estimated. In the absence of wage discrimination in a competitive labor market, the wage differential between the sexes (races) is mainly due to differences in these characteristics if one controls for productivity and taste for work.

As in such analysis, the difference of $\log$ means of the wages of males and females (whites and blacks) is written as:

$$
\begin{aligned}
& \left.\overline{\ln W^{m}}-\overline{\ln W^{f}}=\overline{\left(X^{m}\right.}-\overline{X^{f}}\right)^{\prime} \beta^{m}+\left(\beta^{m}-\beta^{f}\right) \overline{X^{f}}, o r \\
& \left.\overline{\ln W^{m}}-\overline{\ln W^{f}}=\overline{\left(X^{m}\right.}-\overline{X^{f}}\right)^{\prime} \beta^{f}+\left(\beta^{m}-\beta^{f}\right) \overline{X^{m}}
\end{aligned}
$$

where $\overline{W^{m}}, \overline{W^{f}}, \overline{X^{m}}, \overline{X^{f}}$, are the means of male wage (white wage), female wage (black wage), and means of male (white) and female (black) endowments of wage explanatory variables, while $\beta^{m}$ and $\beta^{f}$ are the coefficient estimates for male (white) and female (black) wage equations, respectively. The first expression on the right-hand side of (2a) and (2b) is the part of the male-female (white-black) 
wage differential due to differences in productivity characteristics, and the second expression on the right-hand side of (2) is the part of the differential due to differences in wage structures between males (whites) and females (blacks). This expression is the measure of wage discrimination. As in all decomposition analyses, this measure of discrimination assumes that systematic variation in wages that cannot be explained by the regression equation is due to discrimination. Of course, there could be other explanations for the existence of the wage differentials (e.g., differences in motivation, compensating differential, and efficiency wages, among other explanations).

Whether a researcher uses (2a) or (2b) as the relevant equation depends upon the assumption made about the nature of discrimination. (2a) implies that the wage structure that applies to males (whites) also apply to females (blacks) in the absence of discrimination, and (2b) implies that the female (black) wage applies to males (white) in the absence of discrimination. In general, the measure of wage discrimination in the labor market differs, depending upon whether one uses (2a) or (2b).

In the absence of wage discrimination, given the supplies of labor of each kind, the non-discrimination wage would neither be $W^{m}$ nor $W^{f}$. Suppose males (whites) are in higher demand because of discrimination and hence command premium wages, while females (blacks) are in low demand and hence receive low wages. Elimination of discrimination increases the demand for female (black) labor while it decreases the demand for male (white) labor, all things being equal. In a competitive labor market, these changes will continue until the male (white) and female (black) wage structures converge at $\bar{X} \beta^{*}$. The new equilibrium discrimination-free wage should, therefore, be lower than the male (white) wage but higher than the female (black) wage. For a given vector of characteristics, this implies that: $W^{m} \geq W^{*} \geq W^{f}$ where $W^{*}=X^{\prime} \beta^{*}$ is the discrimination-free wage and $\beta^{*}$ is a vector of coefficients of the discrimination-free wage structure. This discrimination-free wage forms the basis of the alternative decomposition analysis used in this paper. Wage differentials between males (whites) and females (blacks) with the same characteristics could result from males (whites) being paid more than the equilibrium wage by $X^{\prime}\left(\beta^{m}-\beta^{*}\right)$, females (blacks) being underpaid the equilibrium wage by an amount equal to $X^{\prime}\left(\beta^{*}-\beta^{\prime}\right)$, or both. ${ }^{1}$

The foregoing arguments imply that the male-female (white-black) wage differential can be decomposed into a characteristic effect, a male (white) treatment effect, and a female (black) treatment effect. Formally:

$$
\left.\overline{\ln W^{m}}-\overline{\ln W^{f}}=\overline{\left(X^{m}\right.}-\overline{X^{f}}\right)^{\prime} \beta^{*}+\overline{X^{m}}\left(\beta^{m}-\beta^{*}\right)+\overline{X^{f}}\left(\beta^{*}-\beta^{f}\right)
$$


The first term on the right-hand side is the characteristics effect-the wage differential due to differences in productivity, personal, or structural characteristicsand the second and third expressions are the male (white) treatment advantage and female (black) treatment disadvantage, respectively. The sum of the second and third expressions on the right-hand side constitute the measure of wage discrimination.

The problem with the decomposition Equation in (3) is that $\beta^{*}$ is generally not known. However, Neumark (1988) and Cotton (1988) have shown that if it is assumed that the elimination of discrimination does not change the supplies of labor of either sex, then: $W^{*}=s_{m} W^{m}+s_{f} W^{f}=X^{\prime}\left(s_{m} \beta^{m}+s_{f} \beta^{f}\right)$, where $s_{m}$ and $s_{f}$ are the male (white) and female (black) shares in the labor force. ${ }^{2}$ The discrimination-free wage structure is therefore a weighted average of the male (white) and female (black) wage structures. The discrimination-free wage varies with the sexual (racial) composition of the labor force, while $W^{m}$ or $W^{f}$ used in the Oaxaca decomposition is invariant with the sexual (racial) composition. Empirically $\beta^{*}$ can be calculated as the weighted average of $\beta^{m}$ and $\beta^{*}$, that is: $\beta^{*}=$ $s_{m} \beta^{m}+s_{f} \beta^{f}$ (Cotton 1988). Alternatively, $\beta^{*}$ can be obtained by estimating the wage with pooled male and female data. Neumark (1988) has shown that these two approaches provide equivalent estimates of $\beta^{*}{ }^{3}$ We use the latter approach in our decomposition analysis below.

\section{DATA}

The data for this study come from the Current Population Survey (CPS) 1987, March Supplement. The CPS data provides information on wage, education, location, and personal characteristics. In addition, it provides information on occupation and industry of workers. The variables used to estimate the wage equation are derived from the standard human capital model of wage determination. The variables in the $\mathrm{X}$ vector are as follows:

EDUCATION: HIGHSCHOOL, 1YRCOL $-6^{+}$YRCOL: This was measured as dummy variables for high school graduation and each of the number $(1-6$ or more) years of college education. The base for comparison is non-graduation from high school.

EXP, EXP2: years of potential work experience measured as age - years of school - 6.

EXP2 is the square of this variable. ${ }^{4}$

PARTTIME: Dummy variable that equals 1 if the worker worked less than 35 hours per week in the sample period, zero otherwise. 
PARTYEAR: Dummy variable that equals 1 if the worker worked only part of the year regardless of whether he/she worked part time or full time, zero otherwise.

DIVISION (REGION): Dummy variables for U.S. Census Divisions of Middle Atlantic, East North Central, West North Central, South Atlantic, East South Central, West South Central, Mountain, and Pacific, with New England as the reference region (Midwest, South, and West, with Northeast as the reference region). EMPLOY2, EMPLOY3: Dummy variables for whether worker changed employers once, twice, or more during the year, respectively. These are proxy variables intended to capture the impact of firm-specific training on the earning profiles of workers.

BLACK: Dummy variable equal to 1 if worker is black, zero otherwise.

MAR2 - MAR5: Dummy variables for separated, divorced, widowed, never married, with married as the reference group.

CHILDREN: Number of unmarried children under 18 years who live at home.

INDUSTRY: Dummy variables for U.S. Census two-digit industrial classification.

OCCUPATION: Dummy variables for U.S. Census two-digit occupational classifications.

LAMBDA: Sample selectivity bias variable. This variable is included to account for the possibility that individuals in our sample are not randomly selected from the general adult population since the sample consists of only those employed. Lambda is calculated (using Heckman's approach) as: $\left(\hat{Y}, W_{i}\right) / \Phi\left(\hat{Y}, W_{i}\right)$, where (.) is the predicted probability of employment obtained from the probit regression and $\Phi($.)is the cumulative probability of employment from probit function. 5

UR: Unemployment rate in the worker's state of residence. This variable is intended to control for labor demand conditions.

CITY1, CITY2, CITY3: Dummy variables if the worker resided in an MSA of less than 500,000 people, between 500,000 and $2,500,000$, and $2,500,000$ people or greater, respectively, zero otherwise. Non-metropolitan area is the base for comparison. This variable is intended to control for possible wage differentials between rural and urban areas as well as among different sized urban areas.

The variables contained in the $X$ vector have been extensively used by earlier researchers (Cotton 1988; Neumark 1988; Riemers 1983; Gyimah-Brempong, Fichtenbaum, and Willis 1992; Paglin and Rufolo 1990), hence we do not spend time and space to justify their use. Our measure of education differs from the usual manner in which this variable is measured-years of schooling completed. It is possible that there are discontinuities in returns to education that cannot be captured by the traditional way of measuring education. For example, Gyimah-Brem- 
pong, Fichtenbaum, and Willis (1992) find that there is a sharp jump in the returns to education at four years of college education. We therefore measure education in the dummy variable form in order to allow for discontinuities in the returns to education.

Only those reporting earnings are included in the sample. This could introduce sample selectivity bias to our results. To overcome this, we estimated probit equations for the entire sample, as well as various subsets of the sample, to calculate the probability of having eamings. These estimates were then used to calculate the Mill's inverse (Lambda) ratio, which was included in each wage equation to correct for selection bias (Heckman 1979). ${ }^{6}$ The sample used to estimate the wage equations consisted of civilian workers between the ages of 16 and 64 who eamed at least $\$ 1$ or at most $\$ 99$ per hour in wages in either full-time or part-time work. Hourly wages were calculated by dividing annual earnings by weeks worked and hours per week. Data with missing observations were dropped from the sample, leaving a total of 67,787 observations, of which 32,599 were white males, 2,950 black males, 28,814 white females, and 3,536 black females. Geographically, the sample was distributed as follows: New England: 6,284; Middle Atlantic: 10,104; East North Central: 17,174; West North Central: 6,056; South Atlantic: 11,865; East South Central: 3,165; West South Central: 5,861; Mountain: 6,123; and Pacific: 7,992.

Approximately 86 percent of white males finished high school, and 27 percent attended college for at least four years. Among white females, 91 percent finished high school, and 23 percent attended college for at least four years. In contrast, only 77 percent of black males completed high school, and 14 percent attended college for at least four years. Among black females, 84 percent graduated from high school, which is higher than the figure for their male counterparts, although it is considerably lower than their white female counterparts. Finally, only about 15 percent of black females attended at least four years of college. Whites were more likely to have had multiple employers, with 17.3 percent and 16.9 percent of males and females having two or more employers in the previous year, respectively. In contrast, among black males and black females, only 12.8 percent and 12.1 percent, respectively, had two or more employers in the previous year. White females were most likely to work part time ( 29 percent), followed by black females at 21 percent, black males at 11 percent, and white males at 9 percent. Another major difference in employment characteristics is that 25 percent of white males worked only part of the year compared to 31 percent for black males, 35 percent for black females, and 36 percent for white females.

There were small differences between black and white males with respect to industry of employment. However, there were considerable differences in the occupational composition of the two groups. For example, 15 percent of white males 
were in professional or technical occupations, which tend to be high paying, and 7 percent were employed as handlers, equipment cleaners, helpers, and laborers. In contrast, only 8 percent of black males were employed in professional and technical occupations, and 12 percent were handlers, equipment cleaners, helpers, and laborers. There were significant differences between males and females both in industry of employment and occupation. Women were generally in the lower paying industries and occupations. For example, 24 percent of males in the sample worked in manufacturing, and approximately 12 percent worked in professional services. In comparison, only 14 percent of women in the sample worked in manufacturing, and more than 32 percent worked in professional services. Among white women, 18 percent were employed in the professional and technical occupations, 30 percent in administrative support, and 15 percent in service occupations (excluding protective and household services). In contrast, only 12 percent of black women were employed in professional and technical occupations, 27 percent in administrative support, and 23 percent in service occupations (excluding protective and household service).

Finally, there was a major difference between blacks and whites in geographic location. More than 57 percent of blacks in the sample were located in the South, and only 9 percent were located in the West. In contrast, only 28 percent of whites were located in the South, and 22 percent were located in the West. Therefore, blacks from the South may be overrepresented in the sample.

\section{RESULTS}

Coefficient estimates for the U.S. sample are presented in Table $1 .^{7}$ Column 2 presents estimates for white males, column 3 presents the estimates for black males, column 4 presents the estimates for white females, column 5 presents the estimates for black females. Column 6 presents the estimates for the entire sample. Regression statistics indicate a good fit for the wage equations for crosssectional data. The coefficient estimates are of the expected signs and, except in very few cases, are significantly different from zero at conventional significant levels. An interesting result is that while the unemployment rate has a negative impact on the wage rates of blacks and white females, it has no significant effect on the wage rate of white males.

All the traditional human capital variables-education and work experiencehave positive and significant coefficients in all the wage equations as expected. In all estimated wage equations, the retums to education increase with the level of education, with a sharp discontinuity occurring at four years of college education. This seems to justify our measurement of education in dummy variables form. 
TABLE 1

Coefficient Estimates of Wage Equation: National Samples

\begin{tabular}{|c|c|c|c|c|c|}
\hline \multirow[b]{2}{*}{ Variable } & \multicolumn{2}{|c|}{ Male } & \multicolumn{2}{|c|}{ Female } & \multirow[b]{2}{*}{ Total } \\
\hline & White & Black & White & Black & \\
\hline CONSTANT & $\begin{array}{r}1.2578 \\
(27.962)^{a}\end{array}$ & $\begin{array}{r}1.4789 \\
(10.113)\end{array}$ & $\begin{array}{r}1.1105 \\
(9.635)\end{array}$ & $\begin{array}{c}1.6389 \\
(5.019)\end{array}$ & $\begin{array}{r}1.4502 \\
(39.078)\end{array}$ \\
\hline EDUCATION: & & & & & \\
\hline HIGHSCHOOL & $\begin{array}{r}.2455 \\
(17.974)\end{array}$ & $\begin{array}{c}.1348 \\
(3.350)\end{array}$ & $\begin{array}{r}.1802 \\
(4.004)\end{array}$ & $\begin{array}{c}.0642 \\
(1.070)\end{array}$ & $\begin{array}{r}.1523 \\
(12.374)\end{array}$ \\
\hline 1YRCOL & $\begin{array}{r}.3057 \\
(16.384)\end{array}$ & $\begin{array}{r}.2114 \\
(3.302)\end{array}$ & $\begin{array}{r}.2619 \\
(4.755)\end{array}$ & $\begin{array}{c}.1248 \\
(1.519)\end{array}$ & $\begin{array}{r}.2211 \\
(13.402)\end{array}$ \\
\hline 2YRCOL & $\begin{array}{r}.3471 \\
(19.467)\end{array}$ & $\begin{array}{r}2310 \\
(4.061)\end{array}$ & $\begin{array}{r}.3008 \\
(5.117)\end{array}$ & $\begin{array}{r}.0588 \\
(0.591)\end{array}$ & $\begin{array}{r}.2521 \\
(14.994)\end{array}$ \\
\hline 3YRCOL & $\begin{array}{r}.3561 \\
(15.666)\end{array}$ & $\begin{array}{r}.2237 \\
(3.074)\end{array}$ & $\begin{array}{r}.3523 \\
(5.866)\end{array}$ & $\begin{array}{r}.0793 \\
(0.743)\end{array}$ & $\begin{array}{r}.2830 \\
(14.576)\end{array}$ \\
\hline 4YRCOL & $\begin{array}{r}.5216 \\
(27.181)\end{array}$ & $\begin{array}{r}.3104 \\
(4.453)\end{array}$ & $\begin{array}{r}.4163 \\
(6.646)\end{array}$ & $\begin{array}{r}.2485 \\
(2.088)\end{array}$ & $\begin{array}{r}.3967 \\
(21.922)\end{array}$ \\
\hline 5YRCOL & $\begin{array}{r}.4999 \\
(18.101)\end{array}$ & $\begin{array}{r}.3990 \\
(3.734)\end{array}$ & $\begin{array}{r}.5083 \\
(6.971)\end{array}$ & $\begin{array}{r}.3144 \\
(2.328)\end{array}$ & $\begin{array}{r}.4237 \\
(17.714)\end{array}$ \\
\hline $6+\mathrm{YRCOL}$ & $\begin{array}{r}.6598 \\
(29.819)\end{array}$ & $\begin{array}{r}.5128 \\
(5.709)\end{array}$ & $\begin{array}{r}.5884 \\
(7.752)\end{array}$ & $\begin{array}{r}.4127 \\
(3.129)\end{array}$ & $\begin{array}{r}.5276 \\
(25.000)\end{array}$ \\
\hline EXP & $\begin{array}{r}.0303 \\
(18.369)\end{array}$ & $\begin{array}{r}.0337 \\
(6.222)\end{array}$ & $\begin{array}{r}.0214 \\
(9.109)\end{array}$ & $\begin{array}{r}.0105 \\
(1.784)\end{array}$ & $\begin{array}{r}.0203 \\
(18.737)\end{array}$ \\
\hline EXP2 & $\begin{array}{r}-.0005 \\
(10.216)\end{array}$ & $\begin{array}{r}-.0006 \\
(4.611)\end{array}$ & $\begin{array}{r}-.0004 \\
(5.628)\end{array}$ & $\begin{array}{r}-.0001 \\
(0.322)\end{array}$ & $\begin{array}{r}. .0003 \\
(8.715)\end{array}$ \\
\hline MAR2 & $\begin{array}{r}-.0482 \\
(0.866)\end{array}$ & $\begin{array}{r}-.1645 \\
(1.353)\end{array}$ & $\begin{array}{c}.0432 \\
(1.427)\end{array}$ & $\begin{array}{r}-.0145 \\
(0.245)\end{array}$ & $\begin{array}{r}-.0419 \\
(1.972)\end{array}$ \\
\hline MAR3 & $\begin{array}{r}-.1054 \\
(6.124)\end{array}$ & $\begin{array}{r}-.0713 \\
(1.506)\end{array}$ & $\begin{array}{r}.0633 \\
(1.879)\end{array}$ & $\begin{array}{c}-.0716 \\
(0.562)\end{array}$ & $\begin{array}{r}-.0505 \\
(4.895)\end{array}$ \\
\hline MAR4 & $\begin{array}{r}-.0815 \\
(2.834)\end{array}$ & $\begin{array}{r}-.1157 \\
(1.894)\end{array}$ & $\begin{array}{c}-.0597 \\
(2.117)\end{array}$ & $\begin{array}{l}-0.0322 \\
(0.731)\end{array}$ & $\begin{array}{r}-.0843 \\
(4.924)\end{array}$ \\
\hline MAR5 & $\begin{array}{r}-.2265 \\
(13.211)\end{array}$ & $\begin{array}{r}-.1879 \\
(2.905)\end{array}$ & $\begin{array}{c}-.0076 \\
(0.272)\end{array}$ & $\begin{array}{c}0.0138 \\
(0.415)\end{array}$ & $\begin{array}{r}-.1252 \\
(15.123)\end{array}$ \\
\hline EMPLOY2 & $\begin{array}{r}-.1568 \\
(13.574)\end{array}$ & $\begin{array}{r}-.2417 \\
(6.235)\end{array}$ & $\begin{array}{c}-.1213 \\
(9.211)\end{array}$ & $\begin{array}{r}.0117 \\
(0.353)\end{array}$ & $\begin{array}{r}-.1301 \\
(15.683)\end{array}$ \\
\hline EMPLOY3 & $\begin{array}{r}-.1424 \\
(7.838)\end{array}$ & $\begin{array}{r}.0092 \\
(0.156)\end{array}$ & $\begin{array}{c}-.1404 \\
(6.128)\end{array}$ & $\begin{array}{r}-.1625 \\
(2.733)\end{array}$ & $\begin{array}{l}-.12368 \\
(9.057)\end{array}$ \\
\hline CHILDREN & $\begin{array}{r}.0047 \\
(1.237)\end{array}$ & $\begin{array}{r}-.0065 \\
(0.611)\end{array}$ & $\begin{array}{r}-.0274 \\
(5.762)\end{array}$ & $\begin{array}{c}-.0009 \\
(0.093)\end{array}$ & $\begin{array}{c}-.0042 \\
(1.534)\end{array}$ \\
\hline PARTTIME & $\begin{array}{c}-.0985 \\
(6.946)\end{array}$ & $\begin{array}{r}-.0185 \\
(0.492)\end{array}$ & $\begin{array}{c}-.0672 \\
(6.377)\end{array}$ & $\begin{array}{r}-.0104 \\
(0.397)\end{array}$ & $\begin{array}{r}-.0943 \\
(12.236)\end{array}$ \\
\hline PARTYEAR & $\begin{array}{r}-.0539 \\
(5.558)\end{array}$ & $\begin{array}{c}-.0765 \\
(2.842)\end{array}$ & $\begin{array}{r}-.1045 \\
(10.562)\end{array}$ & $\begin{array}{c}-.0912 \\
(4.100)\end{array}$ & $\begin{array}{r}-.0940 \\
(14.565)\end{array}$ \\
\hline UR & $\begin{array}{c}.0029 \\
(1.341)\end{array}$ & $\begin{array}{c}-.0138 \\
(1.923)\end{array}$ & $\begin{array}{c}-.0032 \\
(0.836)\end{array}$ & $\begin{array}{c}-.0106 \\
(1.464)\end{array}$ & $\begin{array}{r}.0046 \\
(2.759)\end{array}$ \\
\hline CITY1 & $\begin{array}{c}.0898 \\
(7.652)\end{array}$ & $\begin{array}{r}.1767 \\
(4.189)\end{array}$ & $\begin{array}{r}.0649 \\
(4.794)\end{array}$ & $\begin{array}{r}.0341 \\
(0.945)\end{array}$ & $\begin{array}{r}.0783 \\
(9.206)\end{array}$ \\
\hline CITY2 & $\begin{array}{r}.1439 \\
(14.051)\end{array}$ & $\begin{array}{r}.2042 \\
(5.866)\end{array}$ & $\begin{array}{r}.1047 \\
(10.274)\end{array}$ & $\begin{array}{r}.1047 \\
(3.438)\end{array}$ & $\begin{array}{r}.1357 \\
(18.305)\end{array}$ \\
\hline CITY3 & $\begin{array}{r}.2539 \\
(25.530)\end{array}$ & $\begin{array}{r}.3286 \\
(10.288)\end{array}$ & $\begin{array}{r}.2384 \\
(15.244)\end{array}$ & $\begin{array}{r}.3016 \\
(9.524)\end{array}$ & $\begin{array}{r}.0861 \\
(35.114)\end{array}$ \\
\hline
\end{tabular}


TABLE 1 (Continued)

\begin{tabular}{|c|c|c|c|c|c|}
\hline \multirow[b]{2}{*}{ Variable } & \multicolumn{2}{|c|}{ Male } & \multicolumn{2}{|c|}{ Female } & \multirow[b]{2}{*}{ Total } \\
\hline & White & Black & White & Black & \\
\hline REGION2 & $\begin{array}{r}-.0754 \\
(6.418)\end{array}$ & $\begin{array}{l}-.0139 \\
(0.34)\end{array}$ & $\begin{array}{c}-.1036 \\
(5.231)\end{array}$ & $\begin{array}{r}-.1130 \\
(3.286)\end{array}$ & -- \\
\hline REGION3 & $\begin{array}{c}-.1136 \\
(9.919)\end{array}$ & $\begin{array}{r}-.1663 \\
(4.427)\end{array}$ & $\begin{array}{c}-.1240 \\
(6.218)\end{array}$ & $\begin{array}{c}-.2696 \\
(8.006)\end{array}$ & -. \\
\hline REGION4 & $\begin{array}{l}-.0295 \\
(2.427)\end{array}$ & $\begin{array}{r}.0222 \\
(0.457)\end{array}$ & $\begin{array}{l}-.0501 \\
(2.825)\end{array}$ & $\begin{array}{c}-.0787 \\
(1.918)\end{array}$ & - \\
\hline DIV2 & $\because-$ & $\because-$ & $\because-$ & $\because$ & $\begin{array}{r}.0730 \\
(5.869)\end{array}$ \\
\hline DIV3 & $\because$ & $\because$ & $\because-$ & $\because$ & $\begin{array}{r}.0035 \\
(0.240)\end{array}$ \\
\hline DIV4 & $\because$ & $\because$ & $\because-$ & $\because-$ & $\begin{array}{r}-.1491 \\
(11.188)\end{array}$ \\
\hline DIV5 & $\because$ & $\because$ & $\because$ &.- & $\begin{array}{r}-.0677 \\
(5.692)\end{array}$ \\
\hline DIV6 & $\because$ & $\because-$ & $\because$ & $\because-$ & $\begin{array}{r}-.1657 \\
(8.488)\end{array}$ \\
\hline DIV7 & $\because$ & $\because$ & $\because-$ & $\because-$ & $\begin{array}{r}-.1082 \\
(6.056)\end{array}$ \\
\hline DIV8 & $\because-$ & $\because$ & $\because$ & $\because$ & $\begin{array}{r}-.0989 \\
(6.456)\end{array}$ \\
\hline DIV9 & $\because$ & $\because$ & $\because$ & $\because$ & $\begin{array}{r}.0723 \\
(5.059)\end{array}$ \\
\hline FEMALE & $\because$ & $\because$ & $\because$ & $\because-$ & $\begin{array}{r}-.1976 \\
(12.950)\end{array}$ \\
\hline BLACK & $\because$ & $\because$ & $\because$ & $\because$ & $\begin{array}{r}-.0106 \\
(1.054)\end{array}$ \\
\hline LAMBDA & $\begin{array}{c}.1170 \\
(1.339)\end{array}$ & $\begin{array}{r}.0811 \\
(0.360)\end{array}$ & $\begin{array}{r}.1343 \\
(0.895)\end{array}$ & $\begin{array}{r}-.4744 \\
(2.584)\end{array}$ & $\begin{array}{c}-.2398 \\
(4.635)\end{array}$ \\
\hline $\begin{array}{c}\text { DEPENDEN } \\
\text { lnWGHR }\end{array}$ & 2.1921 & 1.9613 & 1.7999 & 1.7535 & 1.9926 \\
\hline $\mathbf{N}$ & 32,507 & 2,939 & 28,805 & 3,535 & 67,786 \\
\hline $\bar{R}^{2}$ & .3208 & .3196 & .2086 & .3199 & .3001 \\
\hline $\mathbf{F}$ & 320.817 & 29.756 & 159.179 & 34.573 & 594.228 \\
\hline
\end{tabular}

Absolute value of $\mathrm{t}$ statistics in parentheses. 
The estimates also indicate that the returns to education for whites are higher than the retums to education for blacks at all levels of educational attainment. Indeed for black females, there are no significant returns to education until the attainment of a bachelor's degree. The positive and significant coefficients of education and experience are similar to the results of earlier research.

The coefficients on the city dummy variables indicate that wages in urban areas are higher than in rural areas, but the negative coefficients on the regional (division) dummy variables indicate that wages are higher in the Northeast than anywhere in the United States. While the number of children has no impact on males and black females, it does have a negative and significant impact on the wage of white females. Changing jobs more than once a year or being a part-time or part-year employee has a negative and significant effect on wages-a finding that is consistent with the human capital theory.

Lambda has a negative and significant coefficient in only the black female and the total sample wage equations. An examination of the estimates from all samples suggests that the negative coefficient of Lambda in the wage equation for the total sample is mainly due to the effects of Lambda in the black female sample. The negative and significant coefficient of Lambda implies positive sample selectivity. Failure to account for this positive sample selectivity will bias the coefficient estimates in the wage equation upward, thus overestimating the effects of the independent variables on the black female wage rate. This implies that researchers, especially those using black female data, should take care to correct for sample selection bias when estimating wage equations.

We used the coefficients of the estimated wage equations for the United States and for each of the nine census divisions to decompose the log wage differentials. ${ }^{8}$ The results of the decomposition analyses are presented in Tables 2-5. Table 2 presents decomposition of the male-female wage differential for the nine census divisions and for the United States. Table 3 presents the decomposition of the male-female wage differentials for the four census regions of the United States to be compared with the results in Table 2. Table 4 presents the decomposition of the wage differentials between whites and blacks for the four census regions and the United States, while Table 5 presents decompositions of the wage gaps for samples stratified by gender and race for the four census regions. Only four census regions are used because of the small sample size of blacks in a number of the census divisions.

From the last row of Table 2, we see that the log wage differential between males and females in the United States is .3780, implying a wage differential of $\$ 1.46$ at the means of wages. Of this wage differential, about 40.0 percent is due to differences in endowments of productivity characteristics, and about 60.0 percent of the gender wage gap is due to discrimination. ${ }^{9}$ Contrary to what the 
TABLE 2

Decomposition of Male-Female Wage Differential by Census Division: $1987^{\circ}$

\begin{tabular}{|c|c|c|c|c|c|c|}
\hline Division ${ }^{b}$ & $\mathbf{N}$ & $\begin{array}{l}\text { Wage } \\
\text { Differ- } \\
\text { ential }\end{array}$ & $\begin{array}{l}\text { \% } \\
\text { Cherec- } \\
\text { teristics }\end{array}$ & $\begin{array}{l}\text { \% Male } \\
\text { Treat- } \\
\text { ment }\end{array}$ & $\begin{array}{l}\text { \% Femile } \\
\text { Treet- } \\
\text { ment }\end{array}$ & $\begin{array}{c}\text { \% } \\
\text { Discrimi- } \\
\text { netion }\end{array}$ \\
\hline New England & 6,284 & .3494 & 8.59 & 48.46 & 42.95 & 91.41 \\
\hline Middle Atlantic & 10,104 & .3480 & 59.60 & 18.72 & 21.68 & 40.40 \\
\hline $\begin{array}{l}\text { East North } \\
\text { Central }\end{array}$ & 17,147 & .3918 & 16.59 & 42.36 & 41.05 & 83.41 \\
\hline $\begin{array}{l}\text { West North } \\
\text { Central }\end{array}$ & 6,056 & .4010 & 30.60 & 35.84 & 33.57 & 69.41 \\
\hline South Atlantic & 11,856 & .3709 & 41.28 & 29.72 & 29.00 & 58.72 \\
\hline $\begin{array}{l}\text { East South } \\
\text { Central }\end{array}$ & 3,165 & .3894 & -54.52 & 82.94 & 71.58 & 154.52 \\
\hline $\begin{array}{l}\text { West South } \\
\text { Central }\end{array}$ & 5,861 & .3531 & 40.37 & 28.59 & 31.04 & 59.63 \\
\hline Mountain & 6,123 & .4008 & 95.36 & -1.73 & 6.38 & 4.65 \\
\hline Pacific & 7,993 & .3642 & 41.90 & 28.30 & 29.80 & 58.10 \\
\hline U.S. & 67,787 & .3780 & 39.67 & 30.12 & 30.21 & 60.33 \\
\hline
\end{tabular}

"Wage differential is the log wage differential.

bState composition of the various census divisions are as follows:

New England: $\quad$ ME, NH, VT, MA, RI, and CT

Middle Atlantic: : $\quad \mathrm{NY}, \mathrm{NJ}$, and PA

East North Central: $\quad \mathrm{OH}, \mathrm{IN}, \mathrm{IL}, \mathrm{MI}$, and WI

West North Central: $\quad$ MN, IA, MO, ND, SD, NE, and KS

South Atlantic: $\quad$ DE, MD, DC, VA, WV, NC, SC, GA, and FL

East South Central: $\quad \mathrm{KY}, \mathrm{TN}, \mathrm{AL}$, and MS

West South Central: $\quad$ AR, LA, OK, and TX

Mountain: $\quad$ MT, ID, WY, CO, NM, AZ, UT, and NV

Pacific: $\quad$ WA, OR, CA, AK, and $\mathrm{HI}$. 
TABLE 3

Decomposition of Male-Female Wage Differential by Four Census Regions ${ }^{2}$

\begin{tabular}{|c|c|c|c|c|c|c|}
\hline Trmion $^{b}$ & $\mathbf{N}$ & $\begin{array}{l}\text { Wage } \\
\text { Differ. } \\
\text { entinl }\end{array}$ & $\begin{array}{c}\% \\
\text { Cherec- } \\
\text { teristics }\end{array}$ & $\begin{array}{c}\text { Oo Male } \\
\text { Treat- } \\
\text { ment }\end{array}$ & $\begin{array}{l}\text { \% Female } \\
\text { Treat- } \\
\text { ment }\end{array}$ & $\begin{array}{c}\% \\
\text { Discrimi- } \\
\text { nation }\end{array}$ \\
\hline Northeast & 16,388 & .3481 & 33.05 & 34.16 & 32.79 & 66.95 \\
\hline Midwest & 16,504 & .4103 & 40.99 & 30.00 & 29.00 & 59.00 \\
\hline South & 20,891 & .3674 & 26.41 & 37.43 & 36.17 & 73.60 \\
\hline West & 14,116 & .3785 & 57.40 & 19.52 & 23.08 & 42.60 \\
\hline U.S. & 67,899 & .3780 & 39.67 & 30.12 & 30.21 & 60.33 \\
\hline
\end{tabular}

"Wage differential is the log wage differential.

${ }^{b}$ Composition of the various census regions are as follows:

Northeast: New England and Middle Adlantic

Midwest: $\quad$ East North Central and West North Central

South: $\quad$ South Atlantic, East South Central, and West South Central

West: Mountain and Pacific

TABLE 4

Decomposition of White-Black Wage Differential by Four Census Regions ${ }^{\mathrm{a}}$

\begin{tabular}{lcccccc}
\hline \hline & N & $\begin{array}{c}\text { Wage } \\
\text { Differ- } \\
\text { ential }\end{array}$ & $\begin{array}{c}\text { \% } \\
\text { Charec } \\
\text { teristics }\end{array}$ & $\begin{array}{c}\text { \% White } \\
\text { Treat- } \\
\text { ment }\end{array}$ & $\begin{array}{c}\text { \% Black } \\
\text { Treat- } \\
\text { ment }\end{array}$ & $\begin{array}{c}\text { \% } \\
\text { Discrimi- } \\
\text { nation }\end{array}$ \\
\hline Northeast & 16,375 & .0659 & 83.49 & -0.17 & 16.68 & 16.51 \\
Midwest & 16,478 & .0294 & -7.35 & 3.29 & 104.05 & 107.35 \\
South & 20,850 & .2136 & 73.94 & 4.57 & 21.49 & 26.06 \\
West & 14,084 & .0111 & 110.09 & -8.03 & -2.06 & -10.09 \\
U.S. & 67,787 & .1600 & 68.14 & 2.70 & 29.16 & 31.86 \\
\hline
\end{tabular}

"Wage differential is the log wage differential.

bomposition of the various census regions are as follows:

Northeast: New England and Middle Atlantic

Midwest: $\quad$ East North Central and West North Central

South: $\quad$ South Atlantic, East South Central, and West South Central

West: Mountain and Pacific 
proponents of the human capital model argue, a disproportionately large portion of the wage gap between males and females can be attributed to discrimination in the labor market-a finding that is consistent with the results of a number of previous studies (Blinder 1973; Boston 1988; Gyimah-Brempong, Fichtenbaum, and Willis 1992; Neumark 1988; Riemers 1983; among others). The proportion of the male-female wage differential that is attributable to labor market discrimination is further divided into about 30 percent favorable treatment for males and about 30 percent unfavorable treatment for females. The log mean wage differential between whites and blacks in the United States (as shown in row 5 of Table 4) is .1600 , implying a wage gap of $\$ 1.17$. Of the white-black wage gap, 68.14 percent is attributed to differences in endowments of characteristics, and 31.84 percent can be attributed to discrimination. The proportion of the wage gap attributed to discrimination can be further subdivided into 2.70 percent favorable treatment of whites and 29.16 percent unfavorable treatment of blacks. The composition of the white-black wage gap is similar to the decomposition of the male-female wage gap discussed earlier.

This paper investigates regional differences in labor market discrimination using a decomposition of wages approach. Since the decomposition is based on the coefficient estimates of the wage equation, if these coefficients are the same across regions, there will be no regional differences in labor market discrimination, hence there will be no need to conduct decomposition analysis for the different regions or census divisions. To test whether the estimated coefficients differ across regions and census divisions, we estimated the wage equations for the various census regions (divisions) and race/gender combinations and conducted a generalized Chow test to test for homogeneity of coefficients of the equations across regions (Duffour 1982). ${ }^{10}$ The Chow tests rejected the null hypothesis of no regional differences in the coefficient estimates for all equations. Therefore, we conclude that there are regional differences in the coefficients of the wage equations and proceed to conduct decomposition analyses for the regions and census divisions.

Are there regional differences in the composition of the male-female wage differential? To investigate this question, we conduct decomposition analyses of the male-female wage gap for the nine census divisions using the coefficient estimates from the divisional regressions and compare them with the male-female wage differential for the United States. The results are presented in Table 2. The log of the wage differential between males and females ranges from a low of .371 in the South Atlantic to a high of .401 in the West North Central and Mountain divisions. Four of the divisions-East North Central, West North Central, East South Central, and Mountain-have male-female wage differentials that are higher than the national average, while five divisions have wage differentials that are 
lower than the national average. It is clear from Table 2 that there are regional differences in the male-female wage gap in the United States, although these regional differences are not large in absolute magnitude.

While the range of the log wage differential among the nine census divisions is fairly narrow, there is considerable variation in the factors accounting for the differential. In the Mountain division, with one of the largest wage differentials, virtually all the male-female wage gap ( 95.36 percent) can be explained by differences in productivity characteristics. Only 4.64 percent of the gap can be attributed to differences in retums to characteristics. At the other extreme, in the East South Central division, not only is all the wage differential attributable to discrimination, females are only able to reduce the wage gap (by about a third) with greater endowments of productivity characteristics. In effect, if females in the East South Central division had the same productivity characteristics as their male counterparts, the wage gap would have been $\mathbf{5 4 . 5 2}$ percent larger than the one we observe. Four of the divisions-New England, East North Central, West North Central, and East South Central-show labor market discrimination above the national average, while the West South Central division shows labor market discrimination at just about the national average. Indeed, in New England, with one of the smallest wage gaps among all divisions, about 91 percent of the malefemale wage gap is attributable to differences in returns to characteristics. Overall, the results presented in Table 2 indicate that while there are relatively small differences in male-female differentials across the nine census divisions, there is considerable divisional variation in the degree to which women are discriminated against in the labor market. It is also clear that the divisions with the largest wage gaps are not necessarily those with the largest crude measure of discrimination as measured in this paper.

Does data aggregation over wider geographical area affect the size and composition of wage differentials in the United States? To investigate this question, we partitioned our sample according to the four census regions-Northeast, Midwest, South, and West-instead of the nine divisions as we have in Table 2 and conducted a decomposition analysis for each region. The results of these decomposition analyses are presented in Table 3. As is the case in Table 2, the range of the wage differentials across regions is very narrow-from a high of .410 in the Midwest to a low of .3481 in the Northeast. This level of aggregation still preserves the rankings of the wage gap across regions-the Midwest and the West have larger wage gaps than calculated for the national sample, and the Northeast and the South have wage gaps that are below that of the national sample.

The overall male-female wage differential in the United States remains .378, as does the proportion of the wage differential attributable to discrimination-implying no aggregation bias in the calculation of the wage differential. However, 
large regional differences in the composition of the wage differential emerge when we compare the results in Table 3 to those in Table 2. In Table 3, the proportion of the wage gap attributable to discrimination ranges from a low of 42.60 percent in the West to a high of 73.60 percent in the South. In Table 2 , which shows a much finer geographical disaggregation of data, the proportion of the wage gap attributed to discrimination ranges from a low of 4.65 percent in the Mountain region to a high of 154.52 percent in the East South Central region. While geographical aggregation of data may not result in aggregation bias of the overall estimate of labor market discrimination at the national level, it appears to mask large regional differences in labor market discrimination. These regional differences in labor market discrimination could be important in the formulation and implementation of labor market policies.

From Table 4, we see that the white-black log wage differential is $.1600 .^{11}$ However, this masks large regional differences in the log wage differential. The white-black wage differential varies from a low of .0111 in the West to a high of .2136 in the South. As in the male-female wage gap, there is not a wide regional variation in the wage gap across regions; however, there are large regional differences in the composition of the wage gap. In the Northeast, South, and West, 83.49 percent, 73.94 percent, and 110.90 percent, respectively, of the white-black wage gap can be attributed to differences in endowments of characteristics, and 16.51 percent, 26.06 percent, and -10.09 percent, respectively, can be attributed to discrimination. In effect, blacks have an advantage over whites in the West. In the Midwest, on the other hand, -7.35 percent of the white-black wage gap is due to differences in endowments of characteristics, and discrimination accounts for 107.35 percent of the wage gap. Blacks have to compensate for differences in returns to characteristics with higher endowments of characteristics in order to keep the wage gap at the observed level. As in the male-female wage differential, we see that the region with the largest wage differential-the South-is not the region with the most labor market discrimination against blacks.

Our analysis has so far been conducted in terms of sex and race. It is possible that combining the races (male-female wage gap) or the sexes (white-black wage gap) could confound our results. To reduce this potential problem, we next tum to an examination of differences in earnings in samples stratified by race and sex. We stratify the sample by sex and race, estimate wage equations for the various race and sex stratifications using the national and regional samples, and use the resulting coefficient estimates to decompose the wage differentials by regions. The results are presented in Table 5 ( $A$ and $B$ ).

For white and black males (Table 5, A), the log wage differential ranges from a high of .2898 in the South to a low of .0538 for the West. The components of the wage differentials also differ among the regions. In the Northeast and 
South, discrimination accounts for between 69 percent and 38 percent of the wage differential, respectively, compared to 55 percent for the United States as a whole. In the West and the Midwest, labor market discrimination accounts for about 143 percent and 100 percent, respectively, of the wage differential, while differences in endowments of characteristics are an insignificant determinant of the wage gap in the Midwest. In the West, black males compensate for lower retums with higher endowments of characteristics to keep the wage gap as observed. This regional difference in the composition of the wage gap is consistent with the findings for the male-female wage differentials discussed above.

Panel B of Table 5 presents a decomposition of white female-black female wage differential by region. In all regions except the South, where the white female wage exceeds that of black females, black females had an average wage that was higher than that of their white counterparts. However, because of the concentration of black females in the South, the white female-black female wage differential for the national sample is positive. The composition of the wage differentials also differs among the regions as well as from the U.S. data. While the

TABLE 5

Decomposition of Wage Differentials by Regions

\begin{tabular}{|c|c|c|c|c|c|c|}
\hline \multirow[b]{2}{*}{ Region } & \multicolumn{6}{|c|}{ A. White Male-Black Male Wage Differential } \\
\hline & $\mathbf{N}$ & $\begin{array}{l}\text { Wage } \\
\text { Differ- } \\
\text { ential } \\
\end{array}$ & $\begin{array}{c}\% \\
\text { Charac- } \\
\text { teristics } \\
\end{array}$ & $\begin{array}{c}\text { \% White } \\
\text { Male } \\
\text { Treatment }\end{array}$ & $\begin{array}{l}\text { \% Black } \\
\text { Male } \\
\text { Treatment }\end{array}$ & $\begin{array}{c}\text { \% } \\
\text { Discrimi- } \\
\text { nation }\end{array}$ \\
\hline Northeast & 8,566 & .1277 & 31.18 & 4.29 & 64.53 & 68.82 \\
\hline Midwest & 8,624 & .1079 & 0.49 & 5.72 & 93.79 & 99.51 \\
\hline West & 7,485 & .0538 & -43.08 & 4.82 & 138.27 & 143.09 \\
\hline South & 10,771 & .2898 & 61.84 & 5.95 & 32.31 & 38.16 \\
\hline \multirow[t]{2}{*}{ U.S. } & 35,446 & .2308 & 45.00 & 4.61 & 50.39 & 55.00 \\
\hline & \multicolumn{6}{|c|}{ B. White Female-Black Female Wage Differential } \\
\hline Region & $\mathbf{N}$ & $\begin{array}{l}\text { Wage } \\
\text { Differ- } \\
\text { ential }\end{array}$ & $\begin{array}{c}\% \\
\text { Charac- } \\
\text { teristics }\end{array}$ & $\begin{array}{l}\text { \% White } \\
\text { Female } \\
\text { Treatment }\end{array}$ & $\begin{array}{l}\text { \% Black } \\
\text { Female } \\
\text { Treatment }\end{array}$ & $\begin{array}{c}\% \\
\text { Discrimi- } \\
\text { nation }\end{array}$ \\
\hline Northeast & 7,809 & -.0378 & 8.78 & 5.20 & 86.02 & 91.22 \\
\hline Midwest & 7,853 & -.0863 & 179.20 & -10.66 & -88.53 & -79.19 \\
\hline West & 6,559 & -.0782 & 80.27 & 2.27 & 17.46 & 19.73 \\
\hline South & 10,791 & .0953 & 82.87 & 4.40 & 12.73 & 17.13 \\
\hline U.S. & 33,012 & .0466 & 66.79 & 3.83 & 29.38 & 33.21 \\
\hline
\end{tabular}

"Wage differential is the log wage differential. 
Northeast has a relatively low wage differential, it is the region in which discrimination accounts for the largest proportion of the wage differential. Our data suggests that productivity characteristics account for only 8.78 percent of the wage gap between white and black females in the Northeast, while differential returns to these characteristics account for 91.22 percent. In the Midwest, on the other hand, black females receive higher returns on their endowments of characteristics than their white counterparts. If retums to characteristics were equalized between black and white females, the black female wage advantage in the Midwest would increase by about 45 percent. White females are only partly able to compensate for this huge disadvantage in returns with large endowments of characteristics. $^{12}$

In the West, differential returns account for 20 percent of the wage gap. This implies that equalization of returns across the races would have decreased the black female wage advantage by about 20 percent. The South is the only region where white females have higher hourly wage rates than black females. However, in this case a large part of the wage gap ( 83 percent) is explained by differences in the characteristics of black and white females. This is not surprising given the long-term effects of "separate but equal" education policies in the South. While the log wage differential is similar across regions, there are a lot of regional variations in the proportion of the wage gap attributable to differences in characteristics and retums to these characteristics. ${ }^{13}$

It is clear from the foregoing analysis that there are substantial regional differences in the wage gap found between blacks and whites as well as between males and females. Besides differences in the levels of wage differentials, there are also regional differences in the composition of these wage differentials. In particular, there are wide regional differences in the proportions of the wage gap that is attributable to discrimination. Moreover, the regions with the largest wage differentials tend not to be the regions with the highest degrees of labor market discrimination. The regional wage differentials, as well as the composition of these differentials, diverge from the U.S. wage differential and its composition.

Our results are consistent with O'Neil's findings of regional differences in the black-white wage gap. We find that these regional differences in the wage gap can be attributed to regional differences in endowments of productivity characteristics as well as to regional differences in labor market discrimination. Our results are at variance with those of Kamalich and Polacheck who find no regional variation in labor market discrimination in the United States. Why are our results so different from those of Kamalich and Polacheck? Perhaps, the different results can be attributed to differences in research methodology and to the different samples employed in the two studies. 
The conclusion that there are significant variations in the regional wage differentials and their composition and that these regional wage differentials are also different from that of the United States has implications for labor market research as well as policy. The research implication is that using data for very large geographical aggregation, such as the whole United States, to investigate the extent of labor market discrimination could hide substantial regional variation in labor market discrimination even though, on the average, such aggregation of data may not produce biased estimates of labor market discrimination in the United States as a whole. This is especially true if labor market discrimination is geographically concentrated. It may therefore be important to disaggregate the data by region when investigating labor market discrimination in the United States.

Perhaps our results are more significant for policy purposes. Given that there are regional differences in the levels and composition of the wage differentials, different strategies and policies may be called for in different regions if the policy objective is to narrow the wage gap in the United States. In regions where the major component of the wage gap is due to differences in endowments of productivity characteristics, policy should concentrate on narrowing the gap in the endowments of these characteristics. On the other hand, in regions where a large part of the wage differential is due to discrimination, narrowing the wage gap will involve narrowing the racial (gender) gap in returns to productivity characteristics rather than narrowing the endowment gap of these characteristics. An altemative approach is to help speed up the process of migration of female (black) labor from regions where returns to their characteristics are lower than those of males (whites) to regions where returns to their characteristics are equal to those of males (whites). A "generic" approach to narrowing the wage gap in the United States may be less effective than a policy that targets specific regions with specific policies.

Our results only indicate that there are significant regional differences in labor market discrimination in the United States. However, what may be of interest to policymakers are the causes of such regional differences in labor market discrimination. Are the observed regional differences in labor market discrimination due to different policies in the regions, or are they caused by the pattem of population movements across the United States? To what extent are these regional differences in labor market discrimination a function of differences in the performance of the regional economies? An investigation of these issues would require conducting studies of labor markets in the different regions over several periods. This is the subject of an ongoing research by the authors. 


\section{v. CONCLUSION}

This paper used 1987 Current Population Survey data and a discriminationfree wage structure to investigate regional differences in labor market discrimination in the United States. We find that there are substantial variations in labor market discrimination across regions in the United States and that the extent of labor market discrimination in the regions also differs markedly from that of the United States as whole. The results imply that the search for equal treatment for blacks and females in the U.S. labor market cannot be found only in increasing the endowments of productivity characteristics of these disadvantaged groups. An efficient way of addressing the problem may involve looking at the operation of regional labor markets. A more geographically differentiated approach is needed if the wage gaps are to be effectively reduced.

The results obtained in this paper should be considered as suggestive rather than definitive. This study suffers from the weaknesses inherent in all decomposition analyses-the inability to measure all factors (or to measure them accurately) that affect labor productivity in the wage equation. Coefficients may suffer from the usual biases, hence the resulting decomposition may also be biased. Despite this weakness, we feel that our results point future research in the direction of more geographical disaggregation when studying labor market discrimination.

\section{ENDNOTES}

1. This argument assumes that the wage bill is fixed and that elimination of discrimination only redistributes this wage bill. If the elimination of discrimination changes the labor supplies of the different groups, it does not qualitatively affect our results so long as one group can be substituted for another, it only complicates the algebra. There could be altemative explanations. One such possibility is that the low female wage is due to "capitalist exploitation" of females as males earn the equilibrium wage rate. Of course, this cannot happen in a competitive market.

2. This assumes that workers from different groups are perfect substitutes, which they should be if they are equally productive and the employer cares only about worker productivity. If workers are perfect substitutes, changes in the supply of different workers will only complicate the algebra but will not qualitatively change our analysis.

3. We note that $\beta^{*}$ is not precisely estimated. It is an approximation of the equilibrium wage since, as indicated above, any value between $\beta^{\mathrm{m}}$ and $\beta^{f}$ is an estimate for $\beta^{*}$. 
4. Clearly, this variable is not the best measure of experience, particularly for women. Unfortunately, the CPS data does not provide any other variable that could be used to measure work experience.

5. The Appendix provides a brief rationale for the inclusion of Lambda in the wage equation as well as the list of variables used in the probit equation to calculate Lambda.

6. See the Appendix for a calculation of Lambda.

7. Because of space considerations, coefficients for industrial and occupational classifications are not presented. They are, however, available upon request. We also do not report coefficient estimates for the divisions and the regional wage estimates. They are also available upon request from the authors.

8. Coefficient estimates of the regional/race/gender wage equations used for the decomposition analyses are not reported because of space considerations. They are available upon request from the authors.

9. Our estimates of labor market discrimination may be lower bounds of discrimination in the labor markets. It is possible that the reason why blacks and females possess smaller quantities of productivity characteristics is because of discrimination in educational institutions and discriminatory hiring practices leading to their being disproportionately employed in low-paying industries and occupations. Our approach only accounts for the direct discrimination in the labor market but not the indirect discrimination through discrimination in the process of acquisition of skills and in hiring practices.

10. These equations are the same as those referred to in endnote 8 above.

11. Because of the small number of blacks in the sample, it has not been possible to disaggregate the sample into the nine divisions when we consider the black-white differential. For this reason, we are only able to disaggregate the data into four distinct regions when we conduct the decomposition analysis for wage differentials between the races.

12. We note that this interpretation holds because of the negative whiteblack female wage gap for this region. We do not present a decomposition analyses of the black male-black female wage gap for the regions because of the small sample size for black males in the West.

13. For the sake of completeness, we conducted decomposition analyses of the white male-black female and white male-white female wage gaps for the census regions. The results are not presented for space considerations. However, they are very similar to those of the racial wage gaps presented in Table 5. While the ranges of the regional wage gaps are narrow, there is considerable variation in the composition of the wage gaps across regions. 


\section{REFERENCES}

Blinder, Alan S. "Wage Discrimination: Reduced Form and Structural Estimates." Journal of Human Resources 8, no. 4 (1973): 436-55.

Boston, Danny. Race, Class and Conservatism. New York: Unwin Hyman, 1988.

Butler, Richard. "Estimating Wage Discrimination in the Labor Market." Journal of Human Resources 17, no. 4 (1982): 606-21.

Cotton, Jeremia. "On the Decomposition of Wage Differentials." Review of Economics and Statistics 70, no. 2 (1988): 236-43.

Duffour, Jean Marie. "Generalized Chow Tests for Structural Change: A Cordinate Free Approach." International Economic Review 23 (1982): 606-21.

Filer, Randall. "Male-Female Wage Differentials: The Importance of Compensating Differentials." Industrial and Labor Relations Review 38, no. 3 (1985): 426-37.

Gyimah-Brempong, Kwabena, Rudy Fichtenbaum, and Greg Willis. "The Effects of College Education on the Male-Female Wage Differential." Southern Economic Journal 58, no. 3 (1992): 790-804.

Haberfeld, Yitchak, and Yehouda Shenhav. "Are Women and Blacks Closing the Gap? Salary Discrimination in American Science During the 1970s and 1980s." Industrial and Labor Relations Review 44, no. 1 (1990): 68-82.

Heckman, James. "Sample Selection Bias as a Specification Error." Econometrica 47 (1979): 153-61.

Kamalich, Richard F., and Solomon W. Polachek. "Discrimination: Fact or Fiction? An Examination Using an Altemative Approach." Southern Economic Journal 49, no. 2 (1982) :450-61.

Low, Stuart A., and Daniel J. Villegas. "An Altemative Approach to the Analysis of Wage Differentials." Southern Economic Journal 53, no. 2 (October 1987): 449-462.

Neumark, David. "Employers' Discriminatory Behavior and the Estimation of Wage Discrimination." Journal of Human Resources 23, no. 3 (1988): 279 95.

Oaxaca, Ronald. "Male-Female Wage Differentials in Urban Labor Markets." International Economic Review 14, no. 3 (1973): 693-709.

O'Neil, June. "The Role of Human Capital in Earnings Differences Between Black and White Men." Journal of Economic Perspectives 4, no. 4 (Fall 1990): 25-45.

Paglin, Morton, and Anthony M. Rufolo. "Heterogeneous Human Capital, Occupational Choice, and Male-Female Earnings Differences." Journal of Labor Economics 8, no. 1, pt. 1 (1990): 123-144. 
Reich, Robert. "Postwar Racial Income Differences: Trends and Theories." In The Three Worlds of Labor Economics, edited by G. Mangum and P. Philips.

White Plains, N.Y.: M. E. Sharpe, 1988.

Reimers, Cordelia W. "Labor Market Discrimination Against Hispanic and Black Men." Review of Economics and Statistics 65, no. 4 (1983): 570-79.

Robinson, Michael D., and Phanindra V. Wunnava. "Measuring Direct Discrimination in Labor Markets Using a Frontier Approach: Evidence from CPS Female Earnings Data." Southern Economic Journal 56, no. 1 (1989): 212-218.

\section{APPENDIX}

\section{Calculation of Lambda}

Because the sample is truncated, there is the need to account for the possibility of sample selection. We followed Heckman's (1979) two-stage procedure in calculating Lambda to account for the selectivity bias. The rational behind this sample selectivity variable is as follows: The wage equation that is of primary interest is given as $y=X^{\prime} \beta+\mu$, where $y$ is the wage rate, $X$ is a vector of explanatory variables, $\beta$ is a set of coefficients to be estimated, and $\mu$ is a stochastic error term. However, the wage equation is observed if and only if the worker is employed, and the probability of employment is given as $z^{*}=\gamma^{\prime} W+\varepsilon$, where $W$ is a set of explanatory variables and $\varepsilon$ is a stochastic error term. It follows that the expected value of $y$ given employment is a function of the wage equation $\left(y=X^{\prime} \beta\right.$ $+\mu)$ and the probability of employment $\left(z^{*}=\gamma^{\prime} W+\varepsilon\right)$. Formally: $E$ [y lemployment $]=\beta^{\prime} X+\beta_{\lambda} \lambda($.$) . As argued in the text, \lambda$ is calculated as $\phi\left(\gamma^{\prime} W\right) / \Phi,\left(\gamma^{\prime} W\right)$, where $\phi($.$) is the predicted probability that individual i$ is employed, and $\Phi($.$) is$ the cumulative probability of employment from the probit equation. The equation for $\phi($.$) is given as:$

$[$ Prob Employment $]=\gamma^{\prime} W+\varepsilon$

where $W$ is a vector of regressors, and $\varepsilon$ is an error term. Variables contained in the $W$ vector include: Education, marital status, age, the square of age, unemployment rate, number of children, race, and city. 